\title{
Macular Electrophysiology After Intravitreal Dexamethasone Implant in Patients with Branch Retinal Vein Occlusion
}

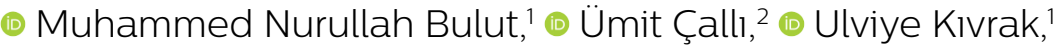 \\ [ Kezban Bulut, ${ }^{1}$ (1) Güzide Akçay ${ }^{1}$
}

\begin{abstract}
'Department of Ophthalmology, University of Health Sciences, Kartal Dr. Lütfi Kırdar Training and Research Hospital, İstanbul, Turkey

${ }^{2}$ Department of Ophthalmology, University of Health Sciences Fatih Sultan Mehmet Training and Research Hospital, İstanbul, Turkey
\end{abstract}

Submitted: 06.08.2019 Accepted: 07.11.2019

Correspondence: Muhammed Nurullah Bulut, Sağlık Bilimleri Üniversitesi Kartal Dr. Lütfi Kırdar Eğitim ve Araştırma Hastanesi, Göz Hastalıkları Kliniği, İstanbul, Turkey

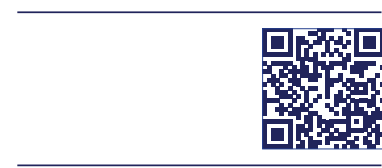

Keywords: Branch retinal vein occlusion; electroretinography; intravitreal dexamethasone implant; macular edema.

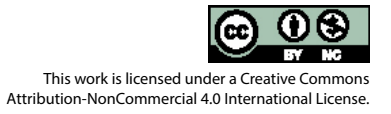

\begin{abstract}
Objective: This study aims to investigate functional changes in the macula by multifocal electroretinography (mfERG) following intravitreal dexamethasone implant for the treatment of macular edema secondary to branch retinal vein occlusion (BRVO).

Methods: Forty-two patients treated with intravitreal dexamethasone implant (Ozurdex ${ }^{\circledR}$, Allergan, Irvine, CA) for macular edema secondary to branch retinal vein occlusion ( 17 male, 25 female, mean age: $58.4 \pm 10.3$ years) were included this study. All patients had a detailed ophthalmological examination, including determination of best-corrected visual acuity, slitlamp examination, dilated fundus examination, optical coherence imaging of the macula and multifocal electroretinography. These examinations were performed in all cases before the intravitreal injection of dexamethasone implant, and the patients were followed with these modalities until six months after implantation.
\end{abstract}

Results: The mfERG changes in rings and effected quadrants were not statistically significant ( $p>0.05$ ). Implicit times in affected quadrants were $38.74 \pm 3.76 \mathrm{~ms}$ and $39.88 \pm 3.63 \mathrm{~ms}$ in preimplantation period and were measured as $38.08 \pm 2.66 \mathrm{~ms}, 38.57 \mathrm{~ms}$ in the post-implantation period. Although $\mathrm{p}$ wave implicit times in all rings and effected quadrants were relatively shorter, the difference was not statistically significant $(p>0.05)$.

Conclusion: Previous reports with first and third month results showed no significant change in mfERG findings in patients with BRVO in the short term. In this study, although a significant increase in visual acuity and a significant decrease in central macular thickness were observed in six months after Ozurdex in BRVO patients, no significant functional change was observed in mfERG.

\section{INTRODUCTION}

Retinal vein occlusion (RVO) is the second most common retinal vascular disease after diabetic retinopathy. ${ }^{[1]}$ RVO almost always occurs at arteriovenous crossings, where arteries and veins share a common adventitia sheath. ${ }^{[2-4]}$ According to the localization of the occlusion, RVO is classified as BRVO and central retinal vein occlusion (CRVO). branch retinal vein occlusion (BRVO) is three times more frequent compared to CRVO and mostly has a better prognosis with the more favorable visual outcome. ${ }^{[5]}$ Macular edema is a frequent complication of RVO and is the most common cause of the reduction in visual acuity in these patients. ${ }^{[6,7]}$ Randomized controlled studies have shown that treatments with laser photocoagulation, ${ }^{[8]}$ intravit- real administration of anti-vascular endothelial growth factors, ${ }^{[9]}$ triamcinolone acetonide ${ }^{[8,10]}$ and dexamethasone implant ${ }^{[1]}$ is effective in the treatment of macular edema and increase visual acuity.

Ozurdex is a biosoluble copolymer of micronized dexamethasone and polylactic acid with glycolic acid. Several studies demonstrated that Ozurdex could reduce macular edema for a six-month period. ${ }^{[I]}$ Although intravitreal dexamethasone implant may cause an increase in intraocular pressure (IOP) in some cases, ${ }^{[1]}$ this condition can be successfully controlled with medical therapy in most cases. The development of cataracts another possible side effect and can also be successfully treated with modern techniques of cataract surgery. This treatment requires less frequent injections compared to the other available 
treatment options, and therefore, may result in a better patient comfort and a lower rate of injection-related complications. ${ }^{[12]}$

Electroretinography (ERG) is a useful tool to evaluate functional changes in retinal diseases, ${ }^{[13]}$ and therefore, found wide use in clinical evaluation and research of various retinal diseases since its first introduction by Sutter and Tren in 1992. ${ }^{[14]} \mathrm{mfERG}$ allows simultaneous recording of focal responses from hundreds of different retinal regions ${ }^{[15]}$ and has been shown to be useful in the evaluation of the retinal dysfunction in RVO patients. ${ }^{[16]}$

This study aims to analyze the effects of dexamethasone intravitreal implant on the recovery of retinal function in BRVO patients with mfERG.

\section{MATERIALS AND METHODS}

This study included 42 patients ( 17 male, 25 female, mean age: $58.4 \pm 10.3$ years) treated with intravitreal dexamethasone implant (Ozurdex ${ }^{\circledR}$, Allergan Inc., Irvine, CA) for macular edema secondary to BRVO, in Kartal Education and Research Hospital, between November 2013 and November 2014. Evaluation of best-corrected visual acuity (BCVA, Snellen), slit-lamp examination of anterior segment and retina, and macular thickness measurements by optic coherence tomography (OCT) were performed for the clinical follow-up of these patients at baseline first, third and sixth month. Multifocal ERG measurements were acquired for all patients before and six months after the administration of intravitreal dexamethasone implant. Snellen acuities converted to logMAR while performing statistical analyses. This study was conducted in accordance with the tenets of the Declaration of Helsinki.

Multifocal ERG was performed according to guidelines of the Internation Society for Clinical Electrophysiology of Vision (17) using the RETI Scan multifocal system (RolandConsul, Brandenburg, Germany). The stimulus consisted of 61 hexagons, and the viewing distance was $26 \mathrm{~cm}$ with a viewing angle of $30^{\circ}$. Disposable Dawson Trick Litzkow (DTL) electrode was preferred. A reference electrode was placed on the glabellar region, and the active electrodes were placed on canthus. Pupils were dilated with $1 \%$ tropicamide in all of the measurements. Measurements were performed +3.00 D near addition after the correction of other refractive errors. $P$ wave amplitude and implicit times were evaluated in all cases. $P$ wave amplitude was the amplitude of the highest positive wave. $P$ wave implicit time was the time interval between the negative peak point and the positive peak point. Ring $P$ waves and $P$ waves in quadrants (Quadrant I and 4 for superior temporal vein occlusion; quadrant 2 and 3 for inferior temporal vein occlusion) were measured to evaluate retinal function. Implicit times were also evaluated similarly.

\section{Statistical analysis}

SPSS 22 for Windows (SPSS Inc, Chicago, IL, USA) software was used for the statistical analysis. The distribution of variables was evaluated using the Kolmogorov-Smirnov test. A paired t-test was used for comparison of repeated measurements. Statistical significance was set at $p<0.05$.

\section{RESULTS}

Twenty-eight patients had superior temporal vein occlusion, and 14 patients had inferior temporal vein occlusion. Pre-implantation central macular thickness (CMT) was 57I.82 $\pm 152.1 \mu \mathrm{m}$ in BRVO patients; CMT was significantly reduced in third-month $(369.8 \pm$ I $10.6 \mu \mathrm{m}, \mathrm{p}<0.05)$ and $6^{\text {th }}$ month $(401.1 \pm 97.96, p<0.05)$. LogMAR visual acu-

Table I. Multifocal electroretinography amplitude changes following intravitreal dexamethasone implant

\begin{tabular}{lccc}
\hline & Baseline & 6. month & p \\
\hline RIaPI & 70.0 & 75.44 & 0.400 \\
R2aPI & 34.97 & 37.6 & 0.560 \\
R3aPI & 21.97 & 22.6 & 0.766 \\
R4aPI & 12.83 & 13.22 & 0.614 \\
R5aPI & 9.32 & 9.01 & 0.704 \\
\hline
\end{tabular}

R: Ring; a: Amplitude. There was no statistically significant difference in any of the ring amplitude measurements between baseline and six months after intravitreal dexamethasone implant $(p>0.005)$.

Table 2. Amplitude and implicit time changes in quadrants

\begin{tabular}{lccc}
\hline & Baseline & 6. month & p \\
\hline Q1-Q4aPI & 13.88 & 14.5 & 0.657 \\
Q2-Q3aPI & 14.76 & 14.96 & 0.614 \\
Q1-Q4iPI & 38.74 & 38.08 & 0.059 \\
Q2-Q3iPI & 39.88 & 38.57 & 0.139 \\
\hline
\end{tabular}

Q: Quadrant; a: Amplitude; i: Implicit time. There were no statistically significant differences in any of the quadrant amplitude or implicit time measurements between baseline and six months after intravitreal dexamethasone implant $(p>0.005)$.

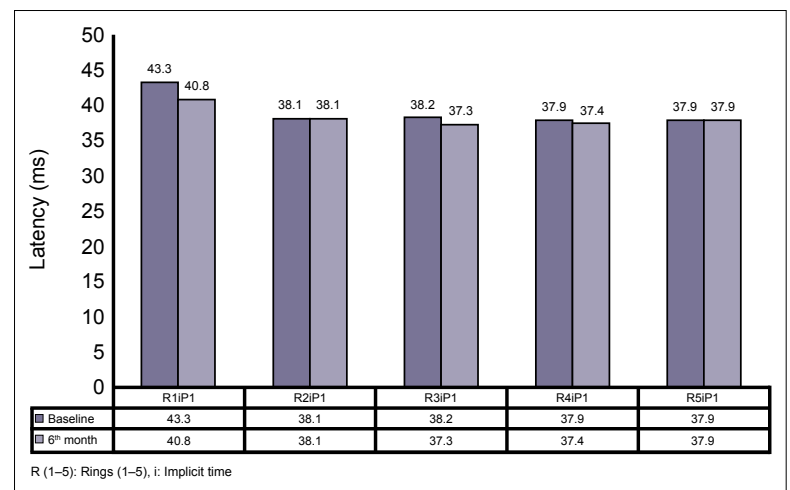

Figure 1. Multifocal electroretinography implicit time changes following intravitreal dexamethasone implant. There were no statistically significant differences in any of the ring implicit time measurements between baseline and six months after intravitreal dexamethasone implant $(p>0.005)$. 
ity was $1.08 \pm 0.5$ before the implantation; and improved significantly in third-month $(0.69 \pm 0.38, p<0.05)$ and sixth -month after implantation $(0.62 \pm 0.37, p<0.05)$.

There were no statistically significant changes between the baseline and $6^{\text {th }}$-month mfERG evaluations for $\mathrm{rl}, \mathrm{r}$, r3, r4 and r5 PI wave amplitudes (Table I). PI wave amplitudes in the affected quadrants of the retina did not change after intravitreal dexamethasone implant administration $(13.88 \pm 5.08$ and $14.76 \pm 4.72$ vs. $14.50 \pm 4.89$ and 14.96 $\pm 5.64, p>0.05)$.

The mfERG implicit time changes for $r l, r 2, r 3, r 4$, and r5 $P$ waves did not show a statistically significant change before and after implantation (Table 2). Implicit times in affected quadrants did not change significantly six months after implantation $(38.74 \pm 3.76 \mathrm{~ms}$ and $39.88 \pm 3.63 \mathrm{~ms}$ vs. $38.08 \pm 2.66 \mathrm{~ms}, 38.57 \pm, \mathrm{p}>0.05$ ) (Fig. I).

\section{DISCUSSION}

There have been several studies about ERG changes in RVO. Full-field ERG (ffERG) represents the whole retinal functional condition. Chen et al. ${ }^{[18]}$ have reported that negative photopic response represents well the functional condition of the retina in BRVO. Another study by Noma et al. ${ }^{\left[{ }^{[1]}\right]}$ demonstrated that implicit time of $b$ wave in the flicker phase (representing cone functions) is increased.

Unlike ffERG, mfERG only indicates the function of the macular region. ${ }^{[20,21]} \mathrm{P}$ wave amplitude and implicit time in mfERG demonstrated the functional damage of the macula and was shown to be reduced in patients with RVO. Dolan et al. ${ }^{[22]}$ reported that $P$ wave amplitude was lower, and implicit time was longer in CRVO. Similarly, lkeda et al. ${ }^{[23]}$ displayed that $\mathbf{P}$ implicit time was delayed in both central region and effected quadrant. Many other studies confirmed that mfERG is abnormal in RVO. ${ }^{[24,25]}$

A relatively recent study reported that there was no statistically significant difference in $\mathrm{P}$ wave amplitude and implicit time in 31 RVO patients one-month after injection of bevacizumab. The authors concluded that bevacizumab was non-toxic to photoreceptors. ${ }^{[26]}$ Park et al. ${ }^{[27]}$ demonstrated in mfERG study that macular function was significantly improved after three consecutive intravitreal bevacizumab injections with six weeks intervals, in addition to the improvement of OCT findings in 19 patients. Another study by Chung et al. ${ }^{[28]}$ reported significant improvements in mfERG among BRVO patients after arteriovenous sheathotomy.

Querques et al. ${ }^{[29]}$ reported that there was no improvement in mfERG in 19 RVO patients after the administration of intravitreal dexamethasone implant. In another study, they have also reported that there was an insignificant trend for improvement after the intravitreal dexamethasone implant, but this improvement faded in mfERG evaluations in the third month. ${ }^{[30]}$

In this study, we did not observe a statistically significant improvement in mfERG findings in BRVO patients treated with intravitreal dexamethasone implant, although there was a statistically significant improvement in visual acuity and in CMT measured with OCT. Our observations confirm the results reported by Querques et al. and indicate that there is still no significant improvement in the sixth month in these patients. ${ }^{[29,30]}$ The question of why the electrophysiological findings do not improve, while visual acuity and OCT findings improve, remains unknown. Future work with longer follow-up periods and repetitive implants would contribute to a better understanding of this subject.

\section{Ethics Committee Approval}

All procedures performed in this research involving human participants were in accordance with the ethical standards of the local research committee.

\section{Peer-review}

Internally peer-reviewed.

Conflict of Interest

None declared.

\section{REFERENCES}

1. Branch Vein Occlusion Study Group. Argon Laser Photocoagulation For Macular Edema In Branch Vein Occlusion. Am J Ophthalmol 2018;196:30-8.

2. Zhao J, Sastry SM, Sperduto RD, Chew EY, Remaley NA. Arteriovenous crossing patterns in branch retinal vein occlusion. The Eye Disease Case-Control Study Group. Ophthalmology 1993;100:4238.

3. Staurenghi G, Lonati C, Aschero M, Orzalesi N. Arteriovenous crossing as a risk factorin branch retinal vein occlusion. Am J Ophthalmol 1994;117:211-3. [CrossRef]

4. Feist RM, Ticho BH, Shapiro MJ, Farber M. Branch retinal vein occlusion andquadratic variation in arteriovenous crossings. Am J Ophthalmol 1992;113:664-8. [CrossRef]

5. Rehak M, Wiedemann P. Retinal vein thrombosis: pathogenesisand management. J Thromb Haemost 2010;8:1886-94. [CrossRef]

6. Rehak J, Rehak M. Branch retinal vein occlusion: pathogenesis,visual prognosis, and treatment modalities. Curr Eye Res 2008;33:111-31.

7. Mohamed Q, McIntosh RL, Saw SM, Wong TY. Interventions for central retinal vein occlusion: an evidence-based systematic review. Ophthalmology 2007;114:507-19. [CrossRef]

8. Mitchell P, Smith W, Chang A. Prevalence and associations of retinal vein occlusion in Australia: the Blue Mountains Eye Study. Arch Ophthalmol 1996;114:1243-7. [CrossRef]

9. Klein R, Klein BE, Moss SE, Meuer SM. The epidemiology of retinal vein occlusion: the Beaver Dam Eye Study. Trans Am Ophthalmol Soc 2000;98:133-41.

10. Central Vein Occlusion Study Group. Natural history and clinical management of central retinal vein occlusion. Arch Ophthalmol 1997;115:486-91. [CrossRef]

11. Haller JA, Bandello F, Belfort R Jr, Blumenkranz MS, Gillies M, Heier J, et al. Dexamethasone intravitreal implant in patients with macular edema related to branch or central retinal vein occlusion twelve-month study results. Ophthalmology 2011;118:2453-60.

12. Haller JA, Bandello F, Belfort R Jr, Blumenkranz MS, Gillies M, Heier J, et al. Randomized, sham-controlled trial of dexamethasone intravitreal implant in patients with macular edema due to retinal vein occlusion. Ophthalmology 2010;117:1134-46.e3. [CrossRef] 
13. Fortune B, Schneck ME, Adams AJ. Multifocal electro-retinogram delays reveal local retinal dysfunction in early diabetic retinopathy. Invest Ophthalmol Vis Sci 1999;40:2638-51.

14. Sutter EE, Tran D. The field topography of ERG components in man-I. The photopic luminance response. Vision Res 1992;32:43346. [CrossRef]

15. Hood DC, Frishman LJ, Saszik S, Viswanathan S. Retinal origins of the primate multifocal ERG: implications for the human response. Invest Ophthalmol Vis Sci 2002;43:1673-85.

16. Abdel-Kader M, El-Dessouky WM. Multifocal electroretinogram in retinal vein occlusion. Saudi J Ophthalmol 2010;24:125-32. [CrossRef]

17. Marmor MF, Hood DC, Keating D, Kondo M, Seeliger MW, Miyake $\mathrm{Y}$, et al. Guidelines for basic multifocal electroretinography (mfERG). Doc Ophthalmol 2003;106:105-15. [CrossRef]

18. Chen $\mathrm{H}, \mathrm{Wu} \mathrm{D}$, Huang $\mathrm{S}$, Yan $\mathrm{H}$. The photopic negative response of the flash electroretinogram in retinal vein occlusion. Doc Ophthalmol 2006;113:53-9. [CrossRef]

19. Noma H, Funatsu H, Mimura T. Association of electroretinographic parameters and inflammatory factors in branch retinal vein occlusion with macular oedema. Br J Ophthalmol 2012;96:1489-93. [CrossRef]

20. Hirose T, Miyake Y, Hara A. Simultaneous recording of electroretinogram and visual evoked response: focal stimulation under direct observation. Arch Ophthalmol 1977;95:1205-8. [CrossRef]

21. Miyake Y, Ichikawa K, Shiose Y, Kawase Y. Hereditary macular dystrophy without visible fundus abnormality. Am J Ophthalmol 1989;108:292-9. [CrossRef]

22. Dolan FM, Parks S, Keating D, Dutton GN, Evans AL. Multifocal electroretinographic features of central retinal vein occlusion. Invest Ophthalmol Vis Sci 2003;44:4954-9. [CrossRef]
23. Ikeda J, Hasegawa S, Suzuki K, Ichibe M, Tanimoto N, Usui T, et al. Multifocal electroretinograms in patients with retinal vein occlusion. [Article in Japanese] Nippon Ganka Gakkai Zasshi 2004;108:8491.

24. Larsson J, Andréasson S. Photopic $30 \mathrm{~Hz}$ flicker ERG as a predictor for rubeosis in central retinal vein occlusion. Br J Ophthalmol 2001;85:683-5. [CrossRef]

25. Williamson TH, Keating D, Bradnam M. Electro-retinography of central retinal vein occlusion under scotopic and photopic conditions: what to measure. Acta Ophthalmol Scand 1997;75:48-53. [CrossRef]

26. Torres-Soriano ME, Cubas-Lorenzo V, García-Aguirre G, Hernández-Rojas M, Kon-Jara V, Díaz-Rubio J, et al. Multifocal electrophysiologic findings after intravitreal bevacizumab (avastin) treatment. Retina 2012;32:972-6. [CrossRef]

27. Park S, Cho IH, Park TK, Nam WH, Ohn YH. Extrafoveal changes following intravitreal bevacizumab injections for macular edema secondary to branch retinal vein occlusion: an mfERG and OCT study. Doc Ophthalmol 2013;126:137-48. [CrossRef]

28. Chung EJ, Freeman WR, Koh HJ. Visual acuity and multifocal electroretinographic changes after arteriovenous crossing sheathotomy for macular edema associated with branch retinal vein occlusion. Retina 2008;28:220-5. [CrossRef]

29. Querques G, Cascavilla ML, Cavallero E, Triolo G, Querques L, Lattanzio R, et al. Changes in macular function after ozurdex for retinal vein occlusion. Optom Vis Sci 2014;91:760-8. [CrossRef]

30. Querques G, Lattanzio R, Querques L, Triolo G, Cascavilla $\mathrm{ML}$, Cavallero E, et al. Impact of intravitreal dexamethasone implant (Ozurdex) on macular morphology and function. Retina 2014;34:330-41.

\section{Retinal Ven Tıkanıklığı Hastalarında Intraviteral Deksametazon İmplant Sonrası Multifokal Elektroretinogram Değişiklikleri}

Amaç: Bu çalışmanın amacı retinal ven dal tıkanıklığında makula ödemi tedavisinde kullanılan intravitreal deksametazon implantın (Ozur$\operatorname{dex}^{\circledast}$, Allergan, Irvine, CA) multifokal elektroretinogram (mfERG) deki etkinliğini gözlemleyerek Ozurdex'in retinanın fonksiyonel yapısındaki etkinliğini incelemektir.

Gereç ve Yöntem: Çalışmamıza Kasım 2013-Kasım 2014 tarihleri arasında retinal ven dal tıkanıklı̆̆ı (RVDT) nedeniyle Ozurdex implant uyguladığımız I7'si erkek toplam 42 hasta dahil edildi. Bütün hastalara Ozurdex uygulaması öncesinde snellen eşeline göre düzeltilmiş en iyi görme keskinliği, biomikroskopik muayene, optik koherent tomografi ile makuler kalınlık ve mfERG ölçümleri yapıldı. Hastalar deksametazon implant öncesi ve sonrası altıncı ayda mf ERG testi uygulandı.

Bulgular: Etkilenen kadranlarda ve ringlerde mfERG değişiklikleri istatsitiksel olarak anlamlı bulunmadı ( $p>0.05)$. RVDT nedeniyle etkilenen kadranda implisit zamanı implantasyon öncesi $38.74 \pm 3.76 \mathrm{~ms}$ iken implantasyon sonrası $38.08 \pm 2.66 \mathrm{~ms}$, olarak ölçüldü. Tüm ringlerde ve etkilenen kadranlarda $p$ dalgasının implisit zamanı kısalmış olsa da bu durum istatistiksel olarak anlamlı bulunmadı.

Sonuç: Daha önce yapılan çalışmalarda Ozurdex sonrası birinci ve üçünvü aylarda mfERG de anlamlı fonksiyonel etki görülmediği raporlanmıştır. Bu çalışmada RVDT hastalarında Ozurdex sonrası altıncı ayda görme keskinliğinde anlamlı artış, santral makula kalınlığında anlamlı azalma görülmesine rağmen mfERG de anlamlı fonskiyonel değişiklik görülmediği sonucuna varıldı.

Anahtar Sözcükler: Deksametazon; elektroretinogram; multifokal. 